\title{
Determination of Arsenic Species in Edible Seaweeds by HPLC-ICP-MS After Pressurized Hot Water Extraction
}

\author{
Jorge Moreda-Piñeiro*a, Cristina García-Sartal ${ }^{\mathrm{b}}$, Carmen Barciela-Alonso ${ }^{\mathrm{b}}$, Purificación López-Mahía ${ }^{\mathrm{a}}$, \\ Soledad Muniategui-Lorenzo ${ }^{a}$, Darío Prada-Rodríguez ${ }^{a}$, and Pilar Bermejo-Barrera ${ }^{b}$ \\ ${ }^{a}$ Grupo Química Analítica Aplicada (QANAP), University Institute of Research in Environmental Studies \\ (IUMA), Centro de Investigaciones Científicas Avanzadas (CICA), Department of Analytical Chemistry, \\ Faculty of Sciences, University of A Coruña, Campus de A Coruña, s/n. 15071 - A Coruña, Spain
}

${ }^{b}$ Department of Analytical Chemistry, Nutrition and Bromatology, Faculty of Chemistry, University of
Santiago de Compostela, Avenida das Ciencias, s/n. E-15782, Santiago de Compostela, Spain

\section{INTRODUCTION}

Seaweed consumption is an attractive alternative food source. Edible seaweeds are commonly commercialized and recommended as health food, diet pills, vitamin supplements, protein source, etc. The human intake of arsenic (As) and other toxic substances occurs mainly via seafood and seaweed ingestion (1). Thus, a careful nutritional and toxicological evaluation of these products is mandatory. Although arsenic concentration in open seawater is extremely low, marine organisms can bio-accumulate inorganic arsenic from the surrounding seawater (2). Toxic arsenic species (arsenite and arsenate) transform into less toxic organoarsenic compounds in seeweeds, mainly arsenobetaine (AB) and dimethylarsinic acid (DMA) in seafood and arsenosugars. The wide-ranging levels of toxicity exhibited by different arsenic species have led to the development of several analytical methods for their extraction and quantification. Arsenic speciation studies focusing mainly on different edible seaweeds include Nori (3-8), Wakame (4-9), Hijiki (4, 5, 10-12), Fucus (5, 13 ), Sea Spaghetti (5), Kombu $(5,7,8)$, Laminaria $(5,6)$, Sargaso $(5,6)$, Sea Lettuce $(7,8,13)$ or Codium (13). The arsenic content in other algae and seaweeds were reported by Arame (5), Hypnea (13),

Cladophora and Chara (14), Turner

\footnotetext{
${ }^{*}$ Corresponding author.

E-mail: jmoreda@udc.es
}

\begin{abstract}
Aqueous soluble arsenic species in Atlantic edible seaweeds have been quantified by high performance liquid chromatography-inductively coupled plasma mass spectrometry (HPLC-ICP-MS). A pressurized high-temperature water extraction (PHWE) method has been developed for arsenic species. The significance of several parameters involved in the arsenic species extraction by PHWE has been evaluated using a PlackettBurman experimental design. The extraction temperature and modifier amounts were optimized by using the central composite design. The extraction procedure was completed within 7 minutes. The analytical performance of the method, such as limit of quantification (in the range of 47 to $101 \mathrm{ng} \mathrm{g}^{-1}$ ), repeatability $(<18 \%)$, column recoveries (in the range of 44 to 99\%), and extraction efficiency (in the range of 32 to $81 \%$ ), was established. The developed method was applied to the arsenic speciation in several edible seaweeds such as Dulse, Nori, Kombu, Wakame, Sea Spaghetti, as well as canned seaweed, and verified by analyzing the certified reference material BCR-279 Sea Lettuce.
\end{abstract}

(15), and Kelp (16). In addition, bioaccessibility and bioavailability studies were developed to assess the bioavailability ratios of toxic and non-toxic arsenic species in edible seaweeds $(4,7,8,17)$.
Several "classic" pre-treatments based on solvents assisted by mechanical shaking $(4,13-15,18)$ and ultrasonic $(3,4,7-9,11,16)$ or microwave $(5,6,12)$ energy have been applied to arsenic species extraction from seaweeds. The main drawback with most of these procedures is that they are very time-consuming. Typical extraction times reported are 15 minutes (3, 4, 16), 30 minutes (11), 60 minutes $(7,8)$, or 180 minutes (9) for ultrasound-assisted extraction (UAE); 5 minutes (12), 15 minutes (5), and 30 minutes (6) for microwaveassisted extraction (MAE); or 120 minutes (18), overnight (15), and 16 hours $(13,14)$ for shaking procedures. Also, the use of large amounts of solvents [de-ionized water (DIW) $(5,9,11-14,18)$, methanol (MeOH)/DIW mixtures $(3,4,15,16)$, ammonium carbonate $(6)$ or ammonium acetate $(7,8)$ buffers] and extract handling (centrifugation steps are required) before analysis are other important disadvantages of these classical procedures. There is, therefore, an interest in developing automated, rapid extraction, and green methods that guarantee high recovery of the analytes.

Pressurized hot water extraction (PHWE) offers short extraction times compared to conventional sample pre-treatment. Also, extract handling is avoided, thus a filtration step is not required. Since no toxic solvents are used, PHWE pre-treatment is considered environmentally friendly. The addition of small amounts of modifiers $[<10 \%(\mathrm{v} / \mathrm{v})]$ to pressurized hot water has been 
usually applied to enhance the solubility of the analytes in water or to increase the interaction of water with the analytes. Several organic (mainly $\mathrm{MeOH}$ ) and inorganic (mainly nitric acid and weak carboxylic acids) substances in the range of 1 to $10 \%(\mathrm{v} / \mathrm{v})$ have been used as modifiers for arsenic and other organometallic compound extractions by PHWE (19, 20). Pressurized hot water, without addition of modifiers, has been successfully applied for arsenic species extraction in plants and vegetables (21, $22)$. The addition of small amounts of modifiers [EDTA $1.2 \%(\mathrm{w} / \mathrm{v})(23)$ or acetic acid $1.0 \%(\mathrm{v} / \mathrm{v})(24)]$ to pressurized hot water has also been proposed for arsenic species extraction in particulate matter (23) and human hair (24). Finally, less "green" extraction methods by using pressurized methanol/water mixtures for the extraction of arsenic species in fish (25), seaweeds (26), seafood (27), and food of animal origin (28) are reported in the literature.

In this work, an automated and fast extraction procedure by using pressurized hot water, modified with small amounts of acetic acid, has been applied to several Atlantic edible seaweeds for aqueous soluble arsenic species extraction with good results.

\section{EXPERIMETAL}

\section{Instrumentation}

An ASE-200 system (Dionex, Sunnyvale, CA, USA), equipped with 11-mL stainless steel cells and cellulose filters (D28, $1.983 \mathrm{~cm}$ diameter, Dionex), was used for PHWE. Arsenic species separation was performed on a Hamilton PRP-X 100 anion-exchange HPLC column (250 $\mathrm{mm} \times 4.1 \mathrm{~mm}$ id $\times 10 \mu \mathrm{m}$ particle size) (Hamilton Company, Reno, Nevada, USA) in a Dionex HPLC Ulti-MateO 3000 LC, equipped with a GP50 gradient pump (Dionex), an AS50 thermal compartment
(Dionex), and an AS-50 auto-sampler (Dionex). An ICP-MS Thermo Finnigan X Series (Thermo Fisher Scientific Inc., Waltham, MA, USA) was used for the quantification of the arsenic species. A Fritsch Planetary Micro Mill Pulverisette 7 ball mill (Fritsch Industriest, Idar-Oberstein, Germany), equipped with zircon cups and zirconium balls, was used to mill the seaweed. Particle-size distribution was obtained by use of a Laser Coulter Series LS200, Fraunhofer optical model particle sizer with an LS variablespeed fluid module plus (Coulter Electronics, Hialeah, FL, USA). A Multiwave $^{\circledR}$ sample preparation system (PerkinElmer, Inc., Shelton, CT, USA), equipped with six Anton Paar (Graz, Austria) reactors programmable for time and microwave power, was used for digestion of the seaweed samples. The chemometrics package of Statgraphics ${ }^{\circledR}$ Plus V 5.0 for Windows ${ }^{\circledR}$, 19941999 (Manugistics, Inc., Rockville, MD, USA) was used for the statistical, graphic, reporting, processing, and tabulating procedures.

\section{Chemicals, Reagents, and Standard Solutions}

All chemicals used were of ultrapure grade, and diluted using water of $18 \mathrm{M} \Omega \cdot \mathrm{cm}^{-1}$ resistance obtained with a Milli-Q ${ }^{\circledR}$ purification system (Millipore Corporation, Bedford, MA, USA). Glacial acetic acid of 99.99\% was used as the modifier and diatomaceous earth (DE) $95 \%$ $\mathrm{SiO}_{2}$ as the dispersing agent (Aldrich, Milwaukee, WI, USA). Nitrogen Alphagaz ${ }^{\mathrm{TM}}$ (Air Liquide, Madrid, Spain) was used as a purge gas. Arsenite [As(III) and arsenate (As(V)], (1000 $\left.\mathrm{mg} \mathrm{L}^{-1}\right)$ stock standard solutions were purchased from Panreac (Barcelona, Spain). Standard solutions of MMA(V), DMA(V) (1.000 $\left.\mathrm{g} \mathrm{L}^{-1}\right)$ were prepared by dissolving the appropriate amounts of MMA(V) $\left[\mathrm{CH}_{3} \mathrm{AsO}\left(\mathrm{ONa}_{2}\right) \cdot 6 \mathrm{H}_{2} \mathrm{O}\right]$ (Carlo Erba, Milan, Italy) and DMA(V)

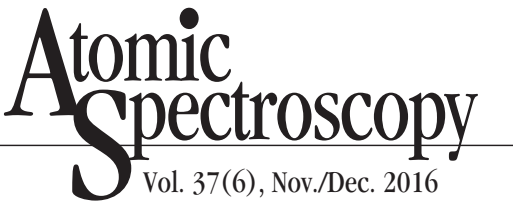

$\left(\mathrm{C}_{2} \mathrm{H}_{6} \mathrm{AsNaO}_{2} \cdot 3 \mathrm{H}_{2} \mathrm{O}\right)($ Merck, Poole, U.K.) in ultrapure water. Ammonium hydrogen carbonate $\left(\mathrm{NH}_{4} \mathrm{HCO}_{3}\right)$ (Panreac) and methanol gradient grade for liquid chromatography (Merck) were used in the mobile phase preparations. Concentrated nitric acid (Merck) and hydrogen peroxide (Panreac) were used to perform the acid digestions. BCR 279 Sea Lettuce, Ulva lactuca, from the Community Bureau of Reference Commission of the European Communities (Brussels, Belgium) was used for method validation. To avoid metal contamination, all glassware and plastic ware was washed and kept for 48 hours in 10\% (v/v) nitric acid, then rinsed several times with ultra-pure water before use.

\section{Edible Seaweed Samples and Sample Pretreatment}

Seven different Atlantic seaweeds, harvested on the Galician coast (Northwestern Spain), were obtained from a local manufacturer. One of the samples is commercialized as cooked and canned in brine (around $25 \mathrm{~g}$ ) and consists of a mixture of Sea Spaghetti (Himanthalia elongata) and Furbelows (Saccorbiza polyschides). This sample was freeze-dried before grinding. The remaining seaweed samples are commercialized as dehydrated products (approximately 100 g): Dulse (Palmaria palmata), Nori (Porphyra umbilicalis), Kombu (Laminaria ochroleuca), Wakame (Undaria pinnatifida), and Sea Spaghetti (Himanthalia elongata). The dehydrated samples were kept in an oven at $40{ }^{\circ} \mathrm{C}$ for 2 hours to eliminate water traces, then pulverized in a vibrating zircon ball mill for 45 minutes (power at $75 \%$ ). The particle-size distribution was determined by laser diffraction spectrometry. The mean particle size after this treatment was approximately $250 \mu \mathrm{m}$. All samples were preserved in precleaned polyethylene bottles. 


\section{Pressurized Liquid Extraction Procedure}

Amounts of $0.5 \mathrm{~g}$ of the homogenized seaweeds were mixed thoroughly with $1.0 \mathrm{~g}$ of inert DE (DE mass / sample mass ratio $=2$ ). The mixture was poured into Dionex standard 11-mL stainless steel extraction cells containing cellulose filters. After closing the cells, they were placed on the carousel of the ASE 200 system, and the samples extracted under the following PHWE conditions: $5.5 \%(\mathrm{v} / \mathrm{v})$ acetic acid, static extraction time of 5 minutes, one extraction cycle, flush volume at $60 \%$, extraction temperature at $110{ }^{\circ} \mathrm{C}$, and extraction pressure at 1500 psi. After the extraction process, the cells were purged for 60 seconds with $\mathrm{N}_{2}$ gas, and the displaced solvent was collected in pre-cleaned glass vials. The total extraction time and the total water-modified volume used were 7 minutes and $20 \mathrm{~mL}$, respectively. The extracts were placed into polyethylene bottles and kept at $4{ }^{\circ} \mathrm{C}$ until analysis. At least two different blanks were performed in each set of PHWE conditions. The extraction cells were cleaned between each run with ultra-pure water. Then, the cells were conditioned with methanol as the solvent using the optimized PHWE conditions (Table I).

\section{TABLE I}

Pressurized Liquid Extraction Conditions

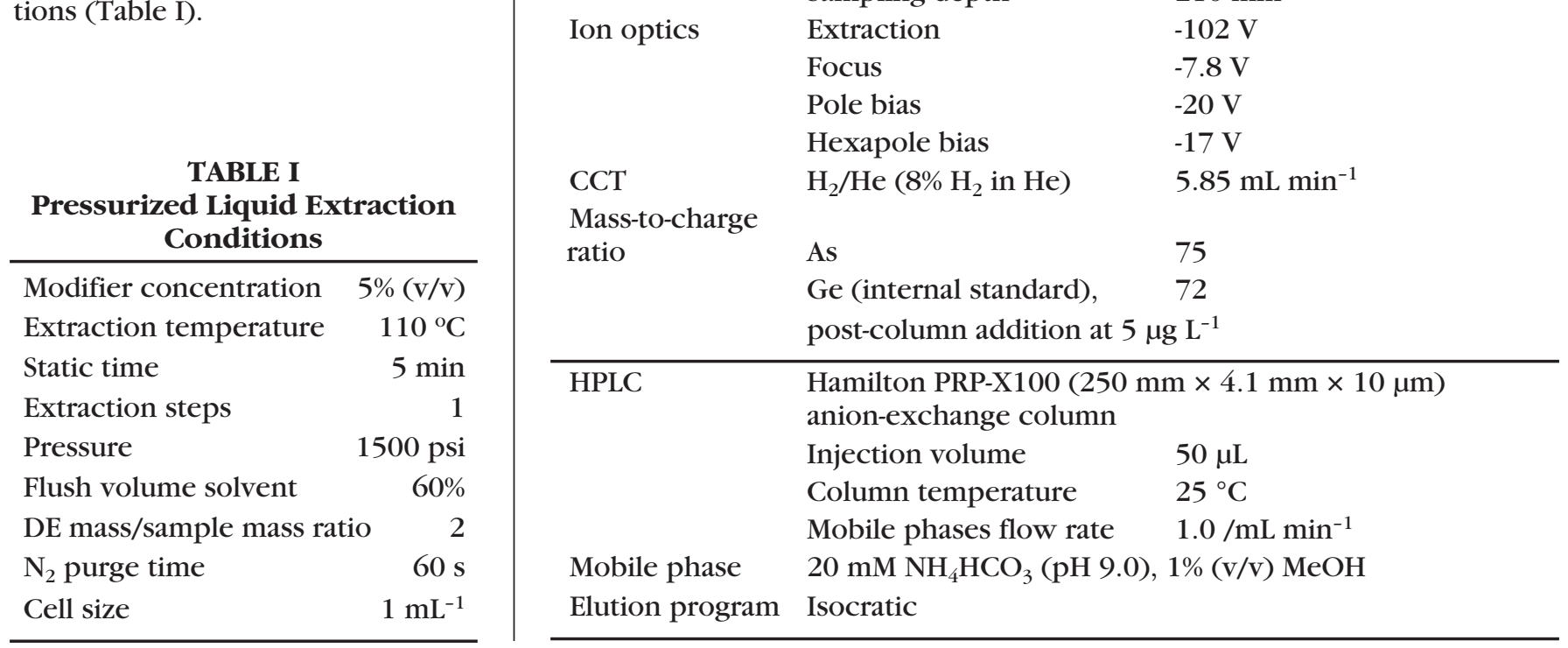

\section{Microwave Acid Digestion Procedure}

The powdered seaweed samples were subjected to an acid microwave-assisted extraction (MAE) to assess the total arsenic content in seaweeds (29). After acid extraction, the solutions were diluted to $25 \mathrm{~mL}$ with ultra-pure water and kept in polyethylene bottles at $4{ }^{\circ} \mathrm{C}$ before measurement.

\section{ICP-MS Measurements}

Total arsenic in the acid digests after microwave acid extraction and total arsenic in the aqueous extracts after PHWE were measured by ICP-MS (24) (Table II). The calibrations were based on
$5.5 \%(\mathrm{v} / \mathrm{v})$ acetic acid aqueous standard solutions covering arsenic concentrations from 0 to $1000 \mu \mathrm{g} \mathrm{L}^{-1}$. Collision cell technology $\left(\mathrm{H}_{2} / \mathrm{He}\right.$ at $5.85 \mathrm{~mL} \mathrm{~min}^{-1}$ ) was used to reduce the $\mathrm{ArCl}(\mathrm{m} / \mathrm{z} 75)$ polyatomic interference. Germanium (10.0 $\left.\mu \mathrm{g} \mathrm{L}^{-1}\right)$ was selected as the internal standard.

After performing different calibrations over six different days, good repeatability of the slopes of the calibrations was obtained. Table III lists the mean and standard deviation of the slopes of the calibration graphs for total arsenic quantification. The limit of detection (LOD) [3 SD criterion, standard deviation (SD) of 11 measurements 
of a reagent blank], expressed as $\mu \mathrm{g}$ $\mathrm{g}^{-1}$, and the limit of quantification LOQ (10 SD criterion) were calculated (see Table III).

\section{HPLC-ICP-MS Measurements}

The anion-exchange HPLC conditions (summarized in Table II) were used to obtain separation of the arsenic species in a single chromatographic run using a Hamilton PRPX100 column and $20 \mathrm{mM}$ $\mathrm{NH}_{4} \mathrm{HCO}_{3}$ (pH 9.0) containing 1.0\% (v/v) $\mathrm{MeOH}$ as the mobile phase (30). The anion-exchange HPLC conditions, as well as the ICP-MS settings, are summarized in Table II. The aqueous calibrations covered arsenic concentrations of 0 , 12.5, 50, 100, and $200 \mu \mathrm{g} \mathrm{L}^{-1}$ (expressed as arsenic) for As(III), As(V), MMA, and DMA. Germanium $\left({ }^{72} \mathrm{Ge}\right)$ at a flow of $5 \mu \mathrm{g} \mathrm{L}^{-1}$ was the internal standard continuously mixing the chromatographic eluate (1.0 $\mathrm{mL} \mathrm{min}^{-1}$ ) at an external flow of the internal standard $\left(1.25 \mathrm{~mL} \mathrm{~min}^{-1}\right)$ via a $T$-junction after the column and just before the nebulizer. Since arsenosugar standards are not available, aqueous calibration for seaweed extracts was achieved by using DMA standards (in the range of 0 to $200 \mu \mathrm{g} \mathrm{L}^{-1}$, expressed as arsenic) for quantification of Gly-Sugar (3-[5'-deoxy-5'-(dimethyl- arsinoyl)- $\beta$-ribofuranosyloxy]-2hydroxypropylene glycol), $\mathrm{PO}_{4-}^{-}$ Sugar (3-[5'-deoxy-5'-(dimethylarsinoyl)- $\beta$-ribofuranosyloxy]-2-hydroxypropyl-2,3-hydroxypropyl phosphate), $\mathrm{SO}_{3}$-Sugar (3-[5'deoxy-5' - (dimethylarsinoyl)- $\beta$-ribofuranosyloxy]-2-hydroxypropane sulfonic acid), and $\mathrm{SO}_{4}-$ Sugar (3[5'-deoxy-5'-(dimethylarsinoyl)- $\beta$ ribofuranosyloxy]-2-hydroxypropyl hydrogen sulfate) (4). Table III lists the mean and the standard deviation of the slopes of the calibration graphs for inorganic arsenic species and DMA and MMA. Good repeatability of the calibration curves was observed over six different days, with a $\%$ RSD of around $16 \%$ in all cases. Keeping in mind the sample weight, the LODs and LOQs, expressed as $\mathrm{ng} \mathrm{g}^{-1}$ (Table III), are low enough to perform arsenic speciation in the seaweed samples (LOQs ranging from 46.9 to $\left.269 \mathrm{ng} \mathrm{g}^{-1}\right)$.

Figure 1 ( $a$ and b) shows typical chromatograms for a mixture of arsenic species standards [As(III), DMA, MMA, and As(V)], and a pooled seaweed sample after applying the proposed extraction and quantification conditions. Identification of the arsenosugar, shown in Figure $1 b$, is based on previous works (7-8). By using the separation

TABLE III

Mean Slopes for Calibration Graphs and Detection and Quantification Limits

\begin{tabular}{lccc}
\hline & $\begin{array}{c}\text { Mean Calibration } \\
\text { Slope } \pm \text { S. D. }\end{array}$ & $\begin{array}{c}\mathrm{LOD}^{\mathrm{b}} \\
\left(\mathrm{ng} \mathrm{g}^{-1}\right)\end{array}$ & $\begin{array}{c}\mathrm{LOQ}^{\mathrm{b}} \\
\left(\mathrm{ng} \mathrm{g}^{-1}\right)\end{array}$ \\
\hline Total As & $0.027 \pm 0.01$ & 1.5 & 6.3 \\
Gly-Sugar & - & $27.2^{\mathrm{c}}$ & $86.7^{\mathrm{c}}$ \\
As(III) & $970 \pm 80$ & 33.5 & 83.4 \\
DMA & $1530 \pm 250$ & 14.9 & 46.9 \\
$\mathrm{PO}_{4}-$ Sugar & - & $22.3^{\mathrm{c}}$ & $72.4^{\mathrm{c}}$ \\
$\mathrm{SO}_{3}$-Sugar & - & $25.4^{\mathrm{c}}$ & $84.2^{\mathrm{c}}$ \\
$\mathrm{MMA}^{\mathrm{SO}}$ & $1980 \pm 340$ & 25.8 & 79.9 \\
$\mathrm{SO}_{4}-$ Sugar & - & $31.7^{\mathrm{c}}$ & $101^{\mathrm{c}}$ \\
As(V) & $390 \pm 60$ & 88.6 & 269 \\
\hline
\end{tabular}

${ }^{a} \mathrm{~N}=6 \quad{ }^{\mathrm{b}} \mathrm{N}=11 \quad{ }^{\mathrm{c}}$ Values achieved using slope from DMA calibration.

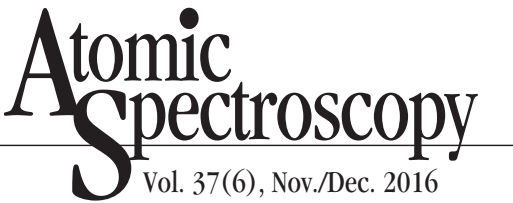

conditions shown in Table II, arsenosugar retention times were assigned after analysis of a lyophilized algal extract of Fucus serratus (containing the four arsenosugars: Gly-Sugar, $\mathrm{PO}_{4}$-Sugar, $\mathrm{SO}_{3}$-Sugar, and $\mathrm{SO}_{4}$-Sugar) kindly donated by Professor Dr. K. A. Francesconi (KarlFranzens University, Graz, Austria) (8). Also, arsenosugar identification was confirmed after electrospray ionization tandem mass spectrometry (ESI-MS/MS) with two-dimensional HPLC (size exclusion, followed by anion exchange) (7).

\section{RESULTS AND DISCUSSION}

\section{Pressurized Hot Water Extraction (PHWE) Procedure Optimization}

Different variables affecting the PHWE (pressure, temperature, static time, number of cycles, sample mass/dispersing agent mass ratio, and modifier amount) for the extraction of aqueous arsenic species in edible seaweeds were fully studied by using the Dionex ASE 200 system.

\section{Selection of Dispersing Agent}

A preliminary experiment was performed to determine the proper dispersing agent for PHWE. A homogenized pooled seaweed sample was selected as the dispersing agent. In order to establish the reference arsenic concentration, the pool was acid-digested four times, and the arsenic concentration measured twice by ICP-MS. The mean arsenic concentration after microwave-assisted acid digestion $(\mathrm{N}=8)$ was $20.1 \pm 0.7 \mathrm{mg} \mathrm{kg}^{-1}$.

Different silica-based solid supports, such as diatomaceous earth (DE), sea sand (SS), octyl-bonded silica, C18, and silica, were tested. PHWE was performed with $0.50 \mathrm{~g}$ of a dry pooled seaweed sample and $1.0 \mathrm{~g}$ of supporting agent (dispersing mass-to-sample mass ratio of 2). Extractions were performed 
using an acetic acid concentration of $6.0 \%(\mathrm{v} / \mathrm{v})$, an extraction temperature of $100{ }^{\circ} \mathrm{C}$ at a pressure of 1500 psi, during 5 minutes, and by using two extraction steps. Two different extractions were performed with each dispersing agent, and a blank was also prepared. The results are shown in Figure 2 for Gly-sugar, DMA, $\mathrm{PO}_{4}$-Sugar, $\mathrm{SO}_{3}$-Sugar, $\mathrm{SO}_{4}$-Sugar, and total arsenic concentrations. It can be seen that the use of DE results in highest arsenic species concentrations.

On the other hand, for inorganic arsenic, high blank signals were found when using SS [150 and 10,200 counts for As(III) and As(V), respectively]. The low blank signals for DE were [110 and 3100 counts for As(III) and As(V), respectively], and for C18 [130 and 1170 counts for As(III) and As(V), respectively]. It must be said that negligible blanks were found for the organic arsenic species by using all dispersing agents. Thus, DE was chosen as the dispersing agent for further experiments.

\section{Factors/Variables for Screening Study -- Variables Affecting As Leaching by PHWE}

A homogenized pooled seaweed sample (with a total arsenic concentration of $20.1 \pm 0.7 \mathrm{mg} \mathrm{kg}^{-1}$ ) was also used for the screening variables study and for further significant variables optimization. For screening and optimization purposes, the response variables were the percentages of the released arsenic species according to the following equation:

\section{Recovery $(\%)=$ CPHWE/CMAE $\times 100$}

where CPHWE is the total arsenic concentration obtained after PHWE and ICP-MS determination (total arsenic) or after PHWE and HPLC-ICP-MS determination (total arsenic as sum of arsenic species), and CMAE is the arsenic concentration after the microwave acid digestion procedure.

A $2^{8} \times 3 / 32$ type III resolution Plackett-Burman design (PBD) for eight factors, four degrees of freedom, 12 runs and two replicates, was chosen to screen the variables affecting the PHWE of arsenic species from edible seaweeds. The variables studied and the field definition of the variables, e.g., the low $(-)$ and high $(+)$ levels assigned to each variable, are listed in Table V.
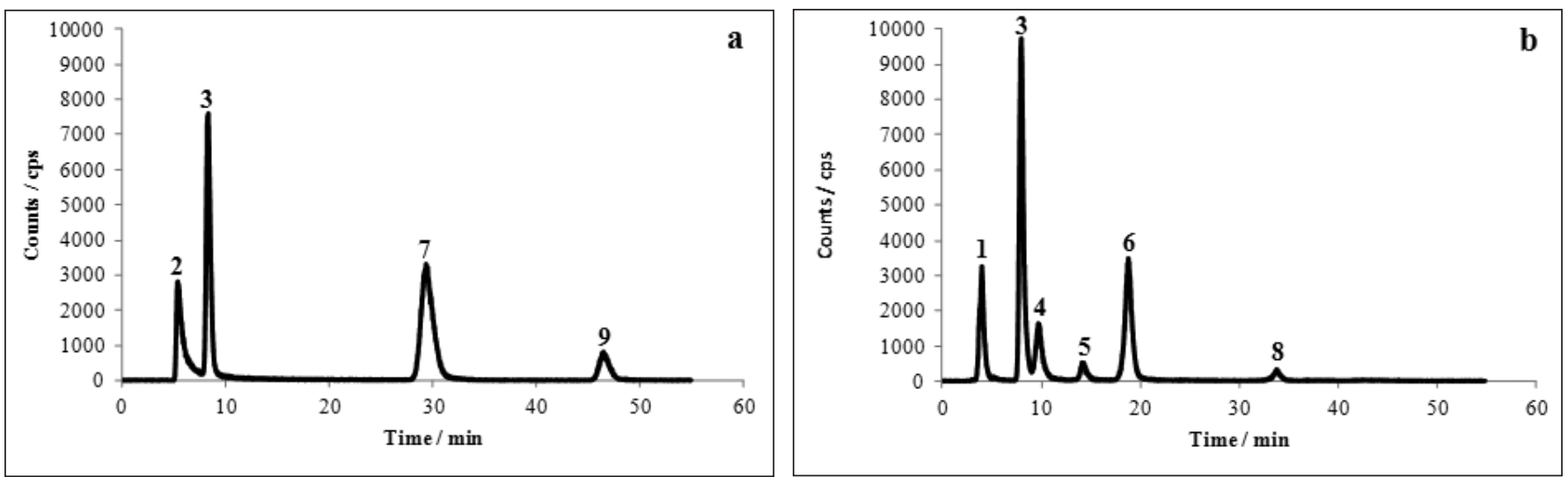

Fig. 1 (a\&b) . HPLC-ICP-MS chromatograms for arsenic species standards: $200 \mu \mathrm{g} L^{-1}$ for As(III), DMA, MMA and As(V) (a); and PHWE extract from pooled seaweed sample using conditions shown in Section 2.7 (b). (1): Gly-Sugar, (2): As(III), (3): DMA, (4): $\mathrm{PO}_{4}$-Sugar, (5): $\mathrm{SO}_{3}$-Sugar, (6): UK, (7): $M M A$, (8): $\mathrm{SO}_{4}$-Sugar and (9): $\mathrm{As}(\mathrm{V})$.

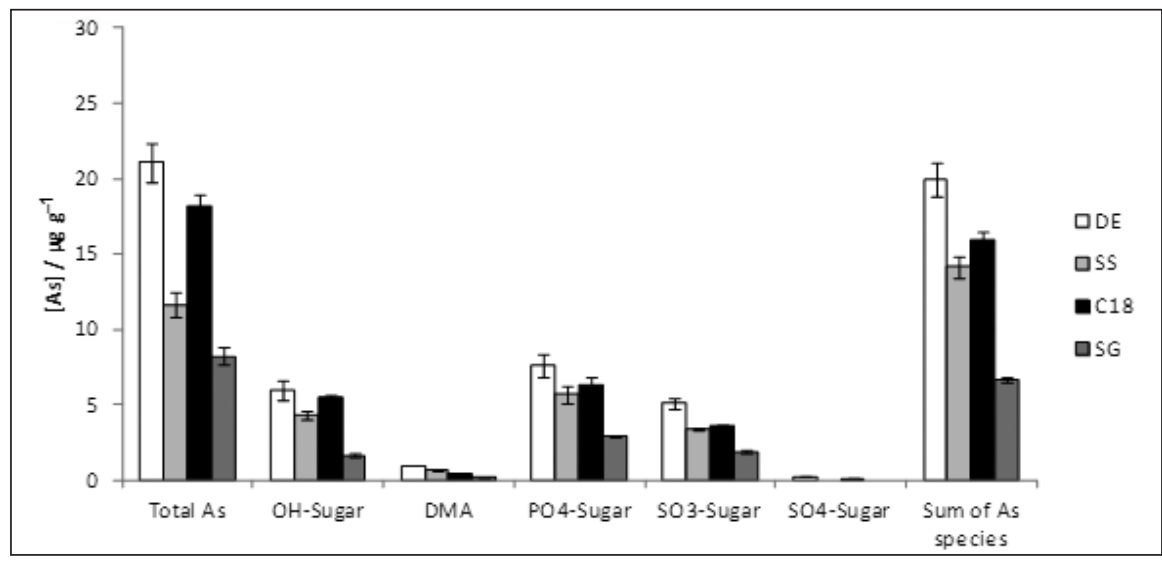

Fig. 2. Effect of the nature of the dispersing agent (diatomaceous earth, DE; sea sand, SS; octyl-bonded silica, C18 and silica gel, SG) for the PHWE of total arsenic, Gly-sugar, DMA, $\mathrm{PO}_{4}$-Sugar, $\mathrm{SO}_{3}$-Sugar, $\mathrm{SO}_{4}$-Sugar and total arsenic as sum of arsenic species from a pooled seaweed sample $(N=2)$. 
The PBD experimental conditions and the values for the response variables are listed in Table V. At a 95.0\% confidence interval, a minimum $t$ value of 3.16 was obtained after the iterative process by the Statigraphic routine. It is stated that variables with $t$ values higher than \pm 3.16 must be considered statistically significant factors. The main effect Pareto Chart (Figure 3) showed statistical significance for some factors, such as for the extrac- tion temperature and the modifier concentration.

The statistically non-significant variables included the selection of lowest extraction time and extraction steps so that PHWE can be performed in the shortest time/sample pulverization to guarantee a certain particle size is not required (mean particle size was not statistically significant in the $100-250 \mu \mathrm{m}$ range); a low DE mass/sample mass

TABLE IV

Experimental Field Definition for the Plackett-Burman (PBD) Designs ${ }^{a}$

\begin{tabular}{lcccc}
\hline Variable & Symbol & $\begin{array}{c}\text { Low Level } \\
(-)\end{array}$ & $\begin{array}{c}\text { High Level } \\
(+)\end{array}$ & Unit \\
\hline Acetic acid concentration & $\mathrm{A}$ & 1.0 & 6.0 & $\%(\mathrm{v} / \mathrm{v})$ \\
Extraction temperature & $\mathrm{T}$ & 25 & 100 & ${ }^{\circ} \mathrm{C}$ \\
Extraction time & $\mathrm{t}$ & 5 & 10 & $\mathrm{~min}$ \\
Extraction step & $\mathrm{S}$ & 1 & 3 & \\
Pressure & $\mathrm{P}$ & 500 & 1500 & $\mathrm{psi}$ \\
Particle size & $\mathrm{S}$ & 125 & 200 & $\mu \mathrm{m}$ \\
DE mass/sample mass ratio & $\mathrm{R}$ & 2 & 5 & \\
Dummy factor & $\mathrm{D}$ & -1 & +1 & \\
\hline
\end{tabular}

${ }^{a} 60 \%$ flush volume, $60 \mathrm{~s} \mathrm{~N}_{2}$ purge time, and cell size of $11 \mathrm{~mL}$.

TABLE V

$2^{8 * 3 / 32}$ PBD for the Determination of Significant Parameters Involved With PHWE

\begin{tabular}{|c|c|c|c|c|c|c|c|c|c|c|}
\hline \multirow[t]{2}{*}{ Run } & \multirow[t]{2}{*}{ A } & \multirow[t]{2}{*}{$\mathrm{T}$} & \multirow[t]{2}{*}{$\mathrm{t}$} & \multirow[t]{2}{*}{$\mathrm{S}$} & \multirow[t]{2}{*}{$\mathrm{P}$} & \multirow[t]{2}{*}{$\mathbf{s}$} & \multirow[t]{2}{*}{$\mathrm{R}$} & \multirow[t]{2}{*}{ D } & \multicolumn{2}{|c|}{$\begin{array}{c}\text { Mean Analytical } \\
\text { Recovery(\%) }\end{array}$} \\
\hline & & & & & & & & & $\begin{array}{c}\text { Total } \\
\mathbf{A s}^{\mathrm{b}}\end{array}$ & $\begin{array}{l}\text { Sum of As } \\
\text { Species }^{\mathrm{c}}\end{array}$ \\
\hline 1 & + & - & + & - & - & - & + & + & 43.4 & 36.9 \\
\hline 2 & + & + & - & + & - & - & - & + & 58.5 & 47.4 \\
\hline 3 & - & + & + & - & + & - & - & - & 46.3 & 38.0 \\
\hline 4 & + & - & + & + & - & + & - & - & 42.1 & 32.9 \\
\hline 5 & + & + & - & + & + & - & + & - & 47.2 & 41.6 \\
\hline 6 & + & + & + & - & + & + & - & + & 52.7 & 42.7 \\
\hline 7 & - & + & + & + & - & + & + & - & 44.5 & 37.8 \\
\hline 8 & - & - & + & + & + & - & + & + & 41.7 & 31.3 \\
\hline 9 & - & - & - & + & + & + & - & + & 33.2 & 26.6 \\
\hline 10 & + & - & - & - & + & + & + & - & 37.7 & 33.6 \\
\hline 11 & - & + & - & - & - & + & + & + & 36.7 & 33.1 \\
\hline 12 & - & - & - & - & - & - & - & - & 33.5 & 30.5 \\
\hline
\end{tabular}

${ }^{\mathrm{a}} \mathrm{N}=2 . \quad{ }^{\mathrm{b}}$ After PHWE and ICP-MS. $\quad{ }^{\mathrm{c}}$ After PHWE and HPLC-ICP-MS.

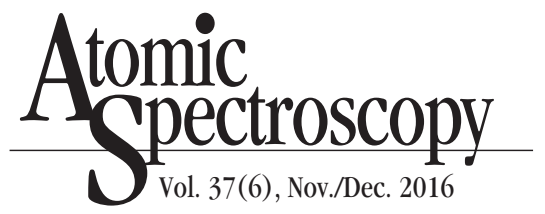

ratio was chosen due to the use of $1.0 \mathrm{~g}$ of DE which facilitates dispersion of the sample and extraction cell filling. The dummy factor was not significant for any of the variables, meaning that there are no systematic errors nor any unknown variables affecting the system under study. For the next stage in the optimization process, extraction time, extraction steps, extraction pressure, and DE mass/sample mass ratio were fixed at 5 minutes, using one extraction step, $1500 \mathrm{psi}$ and the ratio of 2 , respectively.

\section{Optimization of Extraction Temperature and Modifier Concentration by Central Composite Designs}

The optimization of acetic acid concentration (A) and extraction temperature $(\mathrm{T})$ was accomplished by an orthogonal central composite design $\left(2^{2}+\right.$ star $)$ which studied the effects of these factors in 10 randomized runs with 5 degrees of freedom. The low and high values for each factor are shown in Table V. Table VI gives the central composite design matrix and the percentages of released arsenic for each experiment. The results of the experiments were analyzed by the response surface plot obtained for the percentages of total released arsenic (Figure 4a) and the percentages of total released arsenic as the sum of the arsenic species (Figure 4b). Careful study of these results leads to compromise values for acetic acid concentration and extraction temperature of $5.5 \%$ (v/v) and $110^{\circ} \mathrm{C}$, respectively. By using the above optimized conditions, the extraction procedure was completed within 7 minutes.

Determination of Total Arsenic and Arsenic Species in Atlantic Edible Seaweeds

Total arsenic concentrations in several Atlantic seaweeds and in the certified reference material BCR-279 Sea Lettuce (from the 


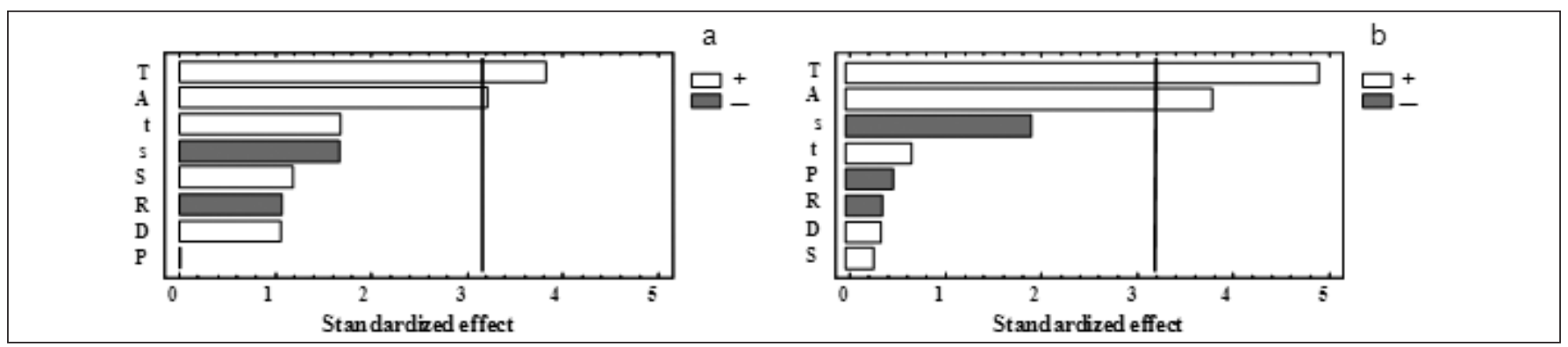

Fig. 3. Main effect Pareto chart for total arsenic extraction (a) and total arsenic extraction as sum of arsenic species (b) by PHWE

Table VI

Central $2^{2}+$ Star Orthogonal Composite Design Used for Acetic Acid Concentration (A) /

Extraction Temperature (T)

\begin{tabular}{llllc}
\hline & & & \multicolumn{2}{c}{$\begin{array}{c}\text { Mean Metal } \\
\text { Recovery(\%) }\end{array}$} \\
\cline { 3 - 5 } $\begin{array}{c}\text { Run } \\
\text { No. }\end{array}$ & \multirow{2}{*}{ A } & T & $\begin{array}{c}\text { Total } \\
\text { As }^{\mathrm{b}}\end{array}$ & $\begin{array}{c}\text { Sum of } \\
\text { As Species }\end{array}$ \\
\hline 1 & $\mathrm{~K}_{0}{ }^{\mathrm{d}}$ & $\mathrm{K}_{0}{ }^{\mathrm{g}}$ & 61.6 & 56.1 \\
2 & - & - & 27.8 & 25.0 \\
3 & + & - & 75.0 & 63.8 \\
4 & - & + & 47.5 & 39.4 \\
5 & + & + & 58.6 & 49.2 \\
6 & $-\alpha^{\mathrm{e}}$ & $\mathrm{K}_{0}{ }^{\mathrm{g}}$ & 26.2 & 23.8 \\
7 & $+\alpha^{\mathrm{f}}$ & $\mathrm{K}_{0}{ }^{\mathrm{g}}$ & 50.2 & 45.2 \\
8 & $\mathrm{~K}_{0}{ }^{\mathrm{d}}$ & $-\alpha^{\mathrm{h}}$ & 29.0 & 25.3 \\
9 & $\mathrm{~K}_{0}{ }^{\mathrm{d}}$ & $+\alpha^{\mathrm{i}}$ & 58.9 & 53.0 \\
10 & $\mathrm{~K}_{0}{ }^{\mathrm{d}}$ & $\mathrm{K}_{0}{ }^{\mathrm{g}}$ & 62.3 & 56.7 \\
\hline
\end{tabular}

${ }^{\mathrm{a}} \mathrm{N}=2 .^{\mathrm{b}}$ After PHWE and ICP-MS.

${ }^{c}$ After PHWE and HPLC-ICP-MS

${ }^{\mathrm{d}} \mathrm{K}_{0}=3.5 \%(\mathrm{v} / \mathrm{v}) .{ }^{\mathrm{e}}-\alpha=0 \%(\mathrm{v} / \mathrm{v})$.

${ }^{\mathrm{f}}+\alpha=7.0 \%(\mathrm{v} / \mathrm{v}) \cdot{ }^{\mathrm{g}} \mathrm{K}_{0}=110{ }^{\circ} \mathrm{C}$.

h $-\alpha=25{ }^{\circ} \mathrm{C} .{ }^{\mathrm{i}}+\alpha=200{ }^{\circ} \mathrm{C}$.

Community Bureau of Reference, Commission of the European Communities) were assessed after a conventional acid digestion, followed by ICP-MS quantification (Table VII). Total arsenic concentrations and total arsenic concentrations (as sum of arsenic species) were also assessed using the pressurized hot water extraction procedure. The repeatability of the over-all procedure was studied by analyzing several seaweed samples for 11 times. Each aqueous extract was analyzed once and the RSD values were lower than $18 \%$ for all cases.
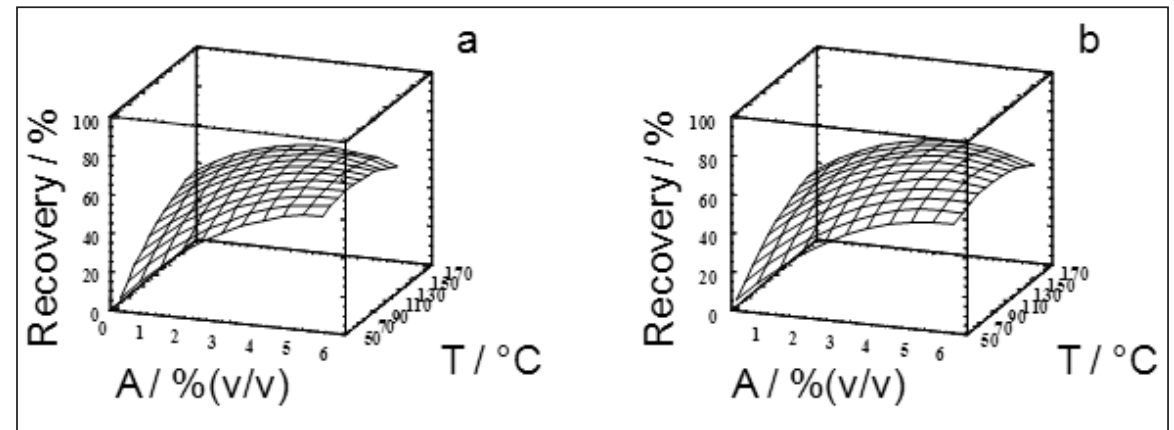

Fig. 4. Estimated response surface for total arsenic extraction (a) and total arsenic extraction as sum of arsenic species (b). Experiments were performed with a static time of 5 min, one extraction step, a pressure of 500 psi, DE mass / sample ratio of $2, \mathrm{~N}_{2}$ purge time of $60 \mathrm{~s}$, and a flush volume of $60 \%$ were used.

\section{Determination of Total Arsenic After Acid Digestion}

Table VII lists the results obtained for total arsenic determination in the cooked seaweed (mixture of Sea Spaghetti and Furbelows) and in five raw edible seaweeds (Dulse, Kombu, Nori, Wakame, and Sea Spaghetti). The total arsenic concentration (after MAE-ICP-MS) varied widely and was in the range of 7.8 to $\mathbf{5 5 . 6}$ $\mu \mathrm{g} \mathrm{g}^{-1}$. These variations are attributable to the species of algae analyzed and other factors, such as collection points, maturity degrees of seaweeds, light intensity, turbidity, temperature, depth, salinity, and nutrient uptake $(4,13,31)$. High arsenic concentrations were obtained for the Kombu $\mathbf{5 5 . 6}$ $\mu \mathrm{g} \mathrm{g}^{-1}$ ) and Nori (39.4-54.4 $\mu \mathrm{g} \mathrm{g}^{-1}$ ) samples. Those levels are in agreement with reported data for Atlantic seaweeds $(5,6,8,32)$. The lowest arsenic value $\left(7.8 \mu \mathrm{g} \mathrm{g}^{-1}\right)$ was found in cooked and canned seaweed (Sea Spaghetti and Furbelows), which could be due to the fact that arsenic dissolves into the cooking water $(8,33)$.

Accuracy of the method was assessed by analyzing BCR-279 Sea Lettuce. The concentration found $\left(3.25 \pm 0.20 \mathrm{mg} \mathrm{kg}^{-1}\right)$ is in good agreement with the certified values (3.09 $\pm 0.21 \mathrm{mg} \mathrm{kg}^{-1}$ ) and was obtained after statistical evaluation by applying the Student's $t$-test at a $95 \%$ confidence level for six degrees of freedom. The tcal value at 2.12 was found to be lower than the $t$ tab value at 2.45 .

\section{Determination Total Arsenic Extractable iton Pressurized Hot Water}

Table VII also shows the amount of total arsenic extracted into the pressurized hot water from the edible seaweeds studied, and also for 
the BCR-279 Sea Lettuce. As commented above for total arsenic extraction by MAE, the total arsenic extractable into pressurized hot water varied widely (5.0-44.1 $\left.\mu \mathrm{g} \mathrm{g}^{-1}\right)$. High arsenic concentrations were obtained for the Kombu and Nori (41.7 and 28.4-44.1 $\mathrm{ug} \mathrm{g}^{-1}$, respectively) samples. The pressurized hot water extraction efficiencies (calculated as the ratio of total arsenic in the water extract to total arsenic in the seaweed, after MAE digestion) were in the range of $65 \%$ (for canned seaweed) to $81 \%$ (for Nori). The extraction efficiencies achieved are in agreement with previously reported data $(3-5,15$, 16, 26), except that the arsenic species are extracted in a very short period of time (extraction was completed within 7 minutes: 5 minutes of extraction time plus one minute of purge time and one minute of end relief). This extraction time is considerably shorter in comparison to classical extraction times as indicated above and reported in the literature. Also, the filtration step was avoided. An arsenic extraction efficiency of $76 \pm 3 \%$ (by using a mixture of MeOH:DIW and sonication) (16) and 67.9-73.3\% (by using MeOH:DIW and pressurization) (26) has been reported for kelp samples. Wei et al. (3), García-Salgado et al. (5), Terol et al. (15), and Raab et al. (18) reported high extraction efficiency for Porphyra sp. (3); Sea Spaghetti, Kombu, Wakame, and Nori (5); Turner (15); and Hijiki and Sea Lettuce (18) when using a mixture of MeOH:DIW plus sonication (90-96\%) (3) or shaking (84-98\%) (15), and by using DIW with shaking $(73-96 \%)(5,18)$. On contrary, Almela et al. reported low extraction efficiencies (in the range of 5 to $73 \%$ ) for raw Kelp, H. fusiforme, U. pinnatifida, Fucus sp. and Porphyra $s p$. when mixtures of MeOH:DIW were used as the extraction solvent (4). Non-quantitative extraction efficiencies can be due to the presence of arsenic lipid- soluble compounds and arsenic bound to proteins which is not extracted into the water ( - ). Recently, the content of lipophilic arsenic species in Saccharina latissima (35), Hijiki (37), and Ectocarpus (38) has been identified and quantified.

Table VII also lists the total arsenic concentration extracted into pressurized hot water for the BCR-279 sample. As can be seen, the hot water extraction efficiency (calculated as the ratio of total arsenic in the water extract to certified value) is $74.5 \%$. This result is in agreement with previously reported data about arsenic extraction by using DIW water as the solvent extraction $(14,18,39)$.

\section{Determination of Arsenic Species Extractable in Pressur- ized Hot Water}

The arsenic species concentrations obtained ranged from 1.2-9.7 $\mu \mathrm{g} \mathrm{g}^{-1}$ for Gly-Sugar, 0.33-2.9 $\mu \mathrm{g} \mathrm{g}^{-1}$ for DMA, $0.25-32.9 \mu \mathrm{g} \mathrm{g}^{-1}$ for $\mathrm{PO}_{4}$-Sugar, <0.08-18.9 $\mu \mathrm{g} \mathrm{g}^{-1}$ for $\mathrm{SO}_{3}$-Sugar, and <0.10-7.0 $\mu \mathrm{g} \mathrm{g}^{-1}$ for $\mathrm{SO}_{4}$-Sugar (Table VII). The MMA and As(III) levels were below the LOQs in all analyzed samples. The As(V) concentrations for these samples, except for Dulse-2, are also below the LOQ. As can be seen, the analyzed seaweeds showed a pattern of arsenic species similar to Gly-Sugar, DMA, and $\mathrm{PO}_{4}-$ Sugar as major species. However, the Nori samples offer a high $\mathrm{PO}_{4}$-Sugar concentration, yet the $\mathrm{SO}_{3}$-Sugar concentration is below the LOQ, and the Sea spaghetii samples offer a high $\mathrm{SO}_{3}$-Sugar concentration. Finally, an unknown arsenic specie was also found in both Dulse samples. Similar Gly- and $\mathrm{PO}_{4}$-Sugar values were reported by García-Salgado et al. (1.6-14.3 and 0.1-20.1 $\mu \mathrm{g} \mathrm{g}^{-1}$, for $\mathrm{Gly}-$ and $\mathrm{PO}_{4}-$ Sugar, respectively) in Sea Spagbetti, Kombu, Wakame, and Nori seaweeds (5) and by Hsieh and Jiang (in the range of 0.34 to $23.7 \mu \mathrm{g} \mathrm{g}^{-1}$

\section{A $_{\text {Sol. } 37(6), \text { Low Doc } 2016}^{\text {tomic }}$}

for Gly-Sugar and 0.834 to $27.3 \mu \mathrm{g}$ $\mathrm{g}^{-1}$ for $\mathrm{PO}_{4}$-Sugar) in Wakame, Kombu, Sargassum, and Porpbyra dentada (6). However, low values for $\mathrm{SO}_{3}$-Sugar (<LOQ-4.2 $\mathrm{gg} \mathrm{g}^{-1}$ ) and $\mathrm{SO}_{4}-$ Sugar $(<\mathrm{LOQ})$, and high values for As(V) (<LOQ-24 $\left.\mu \mathrm{g} \mathrm{g}^{-1}\right)$ were reported (5). Low DMA values $<$ LOQ-0.4 $\mu \mathrm{g} \mathrm{g}^{-1}$ (5) and 0.235-1.3 $\mu \mathrm{g} \mathrm{g}^{-1}$ (6) were also published in these Atlantic seaweeds. As commented above, these variations could be attributed to the species of algae analyzed and other factors (collection points, maturity degrees, light intensity, turbidity, temperature, etc.) $(4,13,40)$.

The efficiency of the arsenic extraction by using pressurized hot water was also evaluated as the percentage of total arsenic (as the sum of arsenic species after PHWEHPLC-ICP-MS) with respect to total arsenic concentration in the sample (after MAE-ICP-MS). The efficiency of the extraction (Table VI) was very variable (40-81\%). Dulse, Kombu and canned seaweeds offer low extraction efficiencies (around 40 to $50 \%$ ). The highest extraction efficiencies were achieved for Nori and Wakame (around 70-80\%). Pell et al. $(13,14)$ reported low extraction efficiencies (as the sum of arsenic species with respect to total arsenic concentration in the sample) in the range of 5 to $69 \%$ in several Cystoseira species, Codium, Ulva species, Cladophora $s p$., and Chara sp when using DIW and mechanical shaking. Hsieh and Jiang (6) reported high extraction efficiencies in Wakame (96\%), Kombu (96\%), Sargassum (92\%) and Porpbyra dentada (89\%) by using a mixture of $\mathrm{MeOH} / \mathrm{ammo}$ nium carbonate and microwave energy. The column efficiency, as the percentage of total arsenic (as the sum of arsenic species after PHWE-HPLC-ICP-MS) with respect to the total arsenic concentration in the aqueous extract injected into the column, was also calculated. The column recoveries ranged 
TABLE VII

PHWE Efficiency and Analysis of Several Atlantic Seaweeds From the Galician Coast After PHWE and HPLC-ICP-MS

\begin{tabular}{|c|c|c|c|c|c|c|c|c|c|c|c|c|c|}
\hline \multicolumn{14}{|c|}{ Concentration (mean value $\pm \mathrm{SD})^{\mathrm{a}}$ Expressed in $\mu \mathrm{g} \mathrm{g}^{-1}$} \\
\hline Sample & $\begin{array}{l}\text { Total } \\
\mathrm{As}^{\mathrm{b}}\end{array}$ & $\begin{array}{c}\text { Total } \\
\text { As }^{\mathrm{c}}\end{array}$ & $\begin{array}{c}\text { Gly- } \\
\text { Sugar }^{c}\end{array}$ & As(III) & DMA & $\begin{array}{c}\mathrm{PO}_{4^{-}} \\
\text {Sugard }^{\mathrm{d}}\end{array}$ & $\begin{array}{l}\mathrm{SO}_{3}^{-} \\
\text {Sugar }^{\mathrm{d}}\end{array}$ & $\begin{array}{c}\text { Un- } \\
\text { known }^{d}\end{array}$ & $\begin{array}{l}\mathrm{SO}_{4-} \\
\text { Sugar }^{\mathrm{d}}\end{array}$ & As $(V)$ & $\begin{array}{l}\text { Total } \\
\text { As as Sum } \\
\text { of As } \\
\text { Species }\end{array}$ & $\begin{array}{c}\text { Column } \\
\text { Recovery } \\
(\%)^{\mathrm{e}}\end{array}$ & $\begin{array}{c}\text { Extrac- } \\
\text { tion } \\
\text { Effici } \\
\text { ency } \\
(\%)^{\mathrm{f}}\end{array}$ \\
\hline Dulse-1 & $16.8 \pm 0.7$ & $11.4 \pm 0.5$ & $4.9 \pm 0.1$ & $<0.08$ & $1.4 \pm 0.1$ & $0.81 \pm 0.02$ & $0.31 \pm 0.01$ & $0.18 \pm 0.02$ & $<0.10$ & $<0.27$ & $7.7 \pm 0.2$ & $66.6 \pm 0.5$ & $45.8 \pm 0.7$ \\
\hline Dulse-2 & $14.9 \pm 0.8$ & $10.6 \pm 0.4$ & $3.5 \pm 0.1$ & $<0.08$ & $0.83 \pm 0.02$ & $0.76 \pm 0.01$ & $0.46 \pm 0.01$ & $0.27 \pm 0.01$ & $0.17 \pm 0.01$ & $<0.27$ & $6.0 \pm 0.1$ & $57.8 \pm 0.4$ & $40.4 \pm 0.8$ \\
\hline Kombu & $55.6 \pm 0.9$ & $41.7 \pm 0.8$ & $7.4 \pm 0.4$ & $<0.08$ & $0.33 \pm 0.01$ & $2.6 \pm 0.2$ & $18.9 \pm 0.5$ & - & $<0.10$ & $<0.27$ & $29.4 \pm 0.7$ & $70.2 \pm 1.1$ & $52.9 \pm 1.1$ \\
\hline Nori-1 & $39.4 \pm 0.6$ & $28.4 \pm 0.3$ & $9.4 \pm 0.5$ & $<0.08$ & $2.9 \pm 0.1$ & $14.3 \pm 0.5$ & $<0.08$ & - & $<0.10$ & $<0.27$ & $26.8 \pm 0.7$ & $93.7 \pm 0.8$ & $67.5 \pm 0.9$ \\
\hline Nori-2 & $54.4 \pm 0.8$ & $44.1 \pm 0.4$ & $9.7 \pm 0.5$ & $<0.08$ & $0.83 \pm 0.02$ & $32.9 \pm 0.5$ & $<0.08$ & - & $<0.10$ & $0.38 \pm 0.02$ & $43.9 \pm 0.7$ & $99.5 \pm 0.8$ & $80.6 \pm 1.1$ \\
\hline Wakame-1 & $8.1 \pm 0.6$ & $5.8 \pm 0.1$ & $2.9 \pm 0.1$ & $<0.08$ & $0.71 \pm 0.02$ & $0.45 \pm 0.03$ & $0.23 \pm 0.01$ & - & $0.11 \pm 0.01$ & $<0.27$ & $4.4 \pm 0.1$ & $76.1 \pm 0.1$ & $54.8 \pm 0.6$ \\
\hline Wakame-2 & $19.3 \pm 1.1$ & $14.5 \pm 0.6$ & $3.1 \pm 0.1$ & $<0.08$ & $1.0 \pm 0.1$ & $4.8 \pm 0.1$ & $5.3 \pm 0.2$ & - & $<0.10$ & $<0.27$ & $14.3 \pm 0.3$ & $98.0 \pm 0.7$ & $73.5 \pm 1.1$ \\
\hline $\begin{array}{l}\text { Sea }-1 \\
\text { spaghetti- } 1\end{array}$ & $\begin{array}{l}21.8 \pm 1.2 \\
1\end{array}$ & $16.4 \pm 0.6$ & $4.2 \pm 0.3$ & $<0.08$ & $0.97 \pm 0.04$ & $0.42 \pm 0.01$ & $4.3 \pm 0.3$ & - & $3.3 \pm 0.1$ & $<0.27$ & $13.2 \pm 0.7$ & $80.5 \pm 0.9$ & $60.4 \pm 1.4$ \\
\hline $\begin{array}{l}\text { Sea } \\
\text { spaghetti }\end{array}$ & $\begin{array}{l}28.9 \pm 0.8 \\
-2\end{array}$ & $20.8 \pm 04$ & $6.5 \pm 0.1$ & $<0.08$ & $0.50 \pm 0.1$ & $0.25 \pm 0.08$ & $5.8 \pm 0.8$ & - & $7.0 \pm 0.2$ & $<0.27$ & $20.2 \pm 0.8$ & $96.6 \pm 0.9$ & $69.8 \pm 1.1$ \\
\hline $\begin{array}{l}\text { Canned } \\
\text { seaweed-1 }\end{array}$ & $7.8 \pm 0.1$ & $5.0 \pm 0.3$ & $1.2 \pm 0.1$ & $<0.08$ & $0.46 \pm 0.01$ & $0.91 \pm 0.01$ & $0.30 \pm 0.01$ & - & $0.38 \pm 0.01$ & $<0.27$ & $3.3 \pm 0.1$ & $65.2 \pm 0.3$ & $42.4 \pm 0.1$ \\
\hline BCR-279 & $3.25 \pm 0.2$ & $2.30 \pm 0.2$ & $0.30 \pm 0.04$ & $\begin{array}{l}0.11 \pm \\
0.01\end{array}$ & $0.05 \pm 0.002$ & $0.08 \pm 0.002$ & $<0.08$ & - & $<0.10$ & $0.47 \pm 0.03$ & $1.0 \pm 0.1$ & $43.5 \pm 0.2$ & $32.4 \pm 0.2^{g}$ \\
\hline
\end{tabular}

\footnotetext{
${ }^{a} \mathrm{~N}=4 .{ }^{\mathrm{b}}$ Concentration after MAE-ICP-MS. ${ }^{\mathrm{c}}$ Concentration after PHWE-ICP-MS. ${ }^{\mathrm{d}}$ Values achieved using slope from DMA calibration.

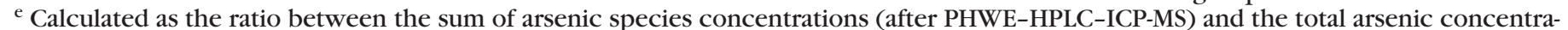

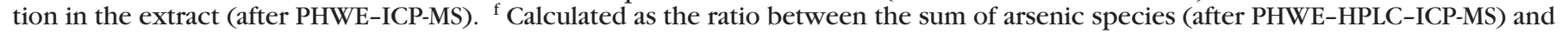

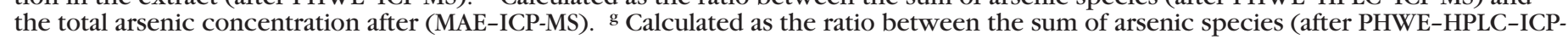

between 58 and 99\% (Table VI).

Canned seaweed offers the lowest

column recoveries (58-67\%). The

cooking process of canned

seaweed might cause changes in the chemical structure of certain arsenic species, which could not be accurately quantified. These results were consistent with column efficiencies reported for several Atlantic seaweeds (5,13-15). The low column recoveries achieved for some samples could be due to (a) the presence of species at concentration levels lower than the LOQs, (b) arsenic species that are not able to elute from the analytical column, (c) the presence of several arsenic compounds that could not be quantified with the separation method used, or (d) the use of DMA stan- dards for arsenosugar quantification $(5,13)$.

Although the arsenic species concentrations in BCR-279 Sea Lettuce are not certified, this reference material was submitted to PHWE and the arsenic concentrations found (after HPLC-ICP-MS) were compared with the concentrations reported for this CRM by other authors. Table VII shows the arsenic species levels extracted in pressurized hot water for the BCR279. Inorganic arsenic and Gly-Sugar were the major arsenic species found. DMA and $\mathrm{PO}_{4}-$ Sugar were also quantified at low concentrations; however, the MMA, $\mathrm{SO}_{3}$-Sugar and $\mathrm{SO}_{4}$-Sugar levels were below the LOQs. Good agree- ment between the found inorganic arsenic concentrations and most of As(III) and As(V) concentrations reported in this CRM were achieved: $0.06 \mu \mathrm{g} \mathrm{g}^{-1}$ for As(III) $(14,18)$ and $0.46 \mu \mathrm{g} \mathrm{g}^{-1}(18)$ and $0.53 \pm 0.04 \mu \mathrm{g} \mathrm{g}^{-1}(14)$ for As(V). Similarly, Gly-Sugar, $\mathrm{PO}_{4}-$ Sugar and DMA contents are not certified in the BCR-279, but some reported concentrations can be found in the literature. The content of Gly-Sugar varied in the range of 0.096 (14) to 0.21 (18) $\mu \mathrm{g} \mathrm{g}^{-1}$. DMA and $\mathrm{PO}_{4}-$ Sugar concentrations found are quite similar to those given by other authors: $0.06 \pm 0.03 \mu \mathrm{g} \mathrm{g}^{-1}$ (14) and $0.07 \mu \mathrm{g} \mathrm{g}^{-1}$ (18) for DMA; and $0.08 \pm 0.01 \mu \mathrm{g} \mathrm{g}^{-1}(14)$ and $0.10 \mu \mathrm{g}$ $\mathrm{g}^{-1}$ (18) for $\mathrm{PO}_{4}-$ Sugar. Hsieh and Jiang (6) reported high aqueous 
arsenic species concentrations: $1.07 \pm 0.012,0.065 \pm 0.003$, $0.200 \pm 0.004,0.302 \pm 0.008$, and $0.674 \pm 0.022 \mu \mathrm{g} \mathrm{g}^{-1}$ for Gly-Sugar, As(III), DMA, $\mathrm{PO}_{4}$-Sugar, and As(V) respectively, by MAE using a mixture of $\mathrm{MeOH} / \mathrm{ammonium}$ carbonate. The hot water extraction efficiency and column recovery (Table VII) are close to previously reported data about arsenic extraction by using water as the solvent extraction $(14,18)$. Raab et al. and Pell et al. reported a total arsenic concentration (as sum of arsenic species) of $1.076 \mu \mathrm{g} \mathrm{g}^{-1}(14)$ and $1.00 \mu \mathrm{g} \mathrm{g}^{-1}$ (18), respectively, in BCR-249. However, Hsieh and Jiang (6) reported high extraction efficiency (84\%). The quantification of species such as arsenobetaine, MMA, and tetramethylarsonium ion in BCR-279 could explain the high extraction efficiency; a total arsenic concentration (as sum of arsenic species) of $2.55 \mu \mathrm{g} \mathrm{g}^{-1}$ was assessed (6).

\section{CONCLUSION}

A green, highly efficient, fast, and automated procedure for arsenic species (mainly arsenosugars) extraction from edible Galician seaweeds has been developed. Pressurized hot water modified with a small amount of acetic acid was used as the green solvent. The arsenic species efficiencies (in the range of 42 to $81 \%$ ) obtained within 7 minutes ( 5 minutes of extraction time plus one minute of purge time and one minute of end relief) were achieved. This extraction time is considerably shorter when compared with classical extraction times proposed in the literature. The steps of extracting solvent addition and extract filtration are totally automated. After factor screening, the extraction temperature and acetic acid concentration are the most significant variables involved in the determination of arsenic species in edible seaweeds by PHWE. Inorganic arsenic (As(III) and As(V)), as well as, MMA, although separated by the HPLC method, were not quantified in any seaweed sample. Gly-Sugar, $\mathrm{PO}_{4}$-Sugar, and $\mathrm{SO}_{3}$-Sugar were the main organic arsenic present in the samples.

\section{ACKNOWLEDGMENT}

The authors wish to thank Xunta de Galicia (Programa de Consolidación y Estructuración de Unidades de Investigación Competitivas 2013-2016, ref: GRC2013-047 and Grupo de Referencia Competitiva ref: 6RC2014/2016), Ministerio de Ciencia y Tecnología (Project number AGL-2006-11034) and Ministerio de Economía y Competitividad (2014-2016, ref:

CTM2013-48194-C3-2-R) for financial support. We are grateful to Alicia María Cantarero-Roldán (Servicios Xerais de Apoio a Investigación at the University of A Coruña) for ICP-MS technical support. We are also grateful to the seaweed-based industry ALGAMAR in Redondela (Pontevedra, Spain) for supplying dried seaweed.

$\overline{\text { Received April 18, } 2016 .}$

\section{REFERENCES}

1. G. Ysart, P. Miller, M. Croasdale, H. Crews, P. Robb, M. Baxter, C. de L'Argy and N. Harrison, Food Addit. Contam. 17, 775 (2000).

2. G. M. Amado, J. C. Creed, L. R. Andrade and W. C. Pfeiffer, Aquat. Bot. 80, 241 (2004).

3. C. Wei, W. Li, C. Zhang, M. Van Hulle, R. Cornelis and X. Zhang, J. Agric. Food Chem. 51, 5176 (2003).

4. C. Almela, J. M. Laparra, D. Vélez, R. Barberá, R. Farré and R. Montoro, J. Agric. Food Chem. 53, 7344 (2005).

5. S. García-Salgado, M. A. Quijano and M. M. Bonilla, Anal. Chim. Acta 714, 38 (2012).

\section{Atomic Apectroscopy 1 Vol. 37(6), Nov./Dec. 2016}

6. Y.-J. Hsieh and S,-J. Jiang, J. Agric. Food Chem. 60, 2083 (2012).

7. C. García-Sartal, S. Taebunpakul, E. Stokes, M. C. Barciela-Alonso, P. Bermejo-Barrera and H. GoenagaInfante, Anal. Bioanal. Chem. 402, 3359 (2012).

8. C. García-Sartal, M. C. Barciela-Alonso and P. Bermejo-Barrera, Microchem. J. 105, 65 (2012)

9. C. Niegel, S. A. Pfeiffer, M. Grundmann, U. Arroyo-Abad, J. Mattusch and F. M. Matysik, Analyst 137, 1956 (2012).

10. Y. Nakajima, Y. Endo, Y. Inoue, K. Yamanaka, K. Kato, H. Wanibuchi and G. Endo, Appl. Organometal. Chem. 20, 557 (2006).

11. Y. Tian, M.-L. Chen, X.-W.Chen, J.H. Wang, Y. Hirano, H. Sakamoto and I. Setsu, J. Anal. At. Spectrom. 25, 48 (2010).

12. S. García-Salgado and M. A. Quijano, Talanta 128, 83 (2014).

13. A. Pell, G. Kokkinis, P. Malea, S. A. Pergantis, R. Rubio and J. F. LópezSánchez, Chemosphere 93, 2187 (2013).

14. A. Pell, A. Márquez, J. F. LópezSánchez, R. Rubio, M. Barbero, S. Stegen, F. Queirolo and P. DíazPalma, Chemosphere 90, 556 (2013).

15. A. Terol, F. Ardini, M. Grotti and J. L. Todolí, J. Chormatogra. A 1262, 70 (2012).

16. L.- L.Yu, C. Wei, R. Zeisler, J. Tong, R. Oflaz, H. Bao and J. Wang, Anal. Bioanal. Chem. 407, 3517 (2015).

17. I. Koch, K. McPherson, P. Smith, L. Easton, K. G. Doe and K. J. Reimer, Mar. Pollut. Bull. 54, 586 (2007).

18. A. Raab, P. Fecher and J. Feldmann, Microchim. Acta 151, 153 (2005).

19. J. Kronholm, K. Hartonen and M. L. Riekkola, Trends Anal. Chem. 26, 396 (2007).

20. E. Alonso-Rodríguez, J. MoredaPiñeiro, P. López-Mahía, D. PradaRodríguez, E.

Fernández-Fernández, S. Muniategui-Lorenzo, A. MoredaPiñeiro, A. Bermejo-Barrera and P. Bermejo-Barrera, Trends, Anal. Chem. 25, 511 (2006). 
21. A. C. Schmidt, W. Reisser, J. Mattusch, P. Popp and R. Wennrich, J. Chormatogra. A 889, 83 (2000).

22. N. P. Vela, D. T. Heitkemper and K. R. Stewart, Analyst 126, 1011 (2001).

23. C. Moscoso-Pérez, J. MoredaPiñeiro, P. López-Mahía, S. Muniategui-Lorenzo, E.

Fernández-Fernández and D. PradaRodríguez, J. Chormatogra. A, 1215, 15 (2008).

24. A. Morado-Piñeiro, J. MoredaPiñeiro, E. Alonso-Rodríguez, P. López-Mahía, S. MuniateguiLorenzo and D. Prada-Rodríguez, Talanta 105, 422 (2013).

25. J. W. McKiernan, J.T. Creed, C. A. Brockhoff, J. A. Caruso and R. M. Lorenzana, J. Anal. At. Spectrom. 14, 607 (1999).

26. P. A. Gallagher, J. A. Shoemaker, X. Y. Wei, C. A. Brockhoff-Schwegel and J. T.Creed, Fresenius J. Anal. Chem. 369, 71 (2001).

27. M. J. Mato-Fernández, J. R. OteroRey, J. Moreda-Piñeiro, E. AlonsoRodrí1guez, P. López-Mahía, S. Muniategui-Lorenzo and D. PradaRodríguez, Talanta 71, 515 (2007).

28. J. Cui, Y. B. Xiao, L. Dai, X. H. Zhao and Y. Wang, Food Anal. Method 6, 370 (2013).

29. J. Moreda-Piñeiro, E. AlonsoRodríguez, P. Lopez-Mahía, S. Muniategui-Lorenzo, D. PradaRodríguez, A. Moreda-Piñeiro and P. Bermejo-Barrera, Anal. Chim. Acta 598, 95 (2007).

30. S. Taebunpakul, C. Liu, C. Wright, K. McAdam, J. Heroult, J. Braybrook and H. Goenaga-Infante, J. Anal. At. Spectrom. 26, 1633 (2011).

31. T. Llorente-Mirandes, M. J. RuizChancho, M. Barbero, R. Rubio and J. F. López- Sánchez, Chemosphere 81, 867 (2010).

32. C. García-Sartal, M. C. BarcielaAlonso, A Moreda-Piñeiro and $\mathrm{P}$ Bermejo-Barrera, Microchem. J. 108, 92 (2013).

33. C. García-Sartal, V. Romarís-Hortas, M. C. Barciela-Alonso, A. MoredaPiñeiro, R. Dominguez-Gonzalez and P. Bermejo-Barrera,
Microchem. J. 98, 91 (2011).

34. K. A. Francesconi, Appl.

Organomet. Chem. 17, 682 (2003).

35. A. Raab, C. Newcombe, D. Pitton, R. Ebel and J. Feldmann, Anal. Chem. 85, 2817 (2013).

36. I. Koch, L. Wang, C. A. Ollson, W. R. Cullen and K. J. Reimer, Environ. Sci. Technol. 34, 22 (2000).

37. R. A. Glabonjat, G. Raber, K. B. Jensen, J. Ehgartner and K. A. Francesconi, Anal. Chem. 86, 10282 (2014).

38. A. H. Petursdottir, K. Fletcher, H. Gunnlaugsdottir, E. Krupp, F. C. Kupper and J. Feldmann, Environ. Chem., 13, 21 (2016).

39. S. Foster, W. Maher, F. Krikowa and S. Apte, Talanta 71, 537 (2007).

40. T. Llorente-Mirandes, M. J. RuizChancho, M. Barbero, R. Rubio and J. F. López-Sánchez, Chemosphere 81,867 (2010). 